\title{
Monetary Policy and Inflation
}

\author{
A speech given by DARRYL R. FRANCIS, President, Federal Reserve Bank \\ of St. Louis, to the 79th Annual Convention of the Arkansas Bankers \\ Association, Arlington Hotel, Hot Springs, Arkansas, May 12, 1969
}

T IS GOOD to have this opportunity to discuss some important policy issues with Arkansas Bankers. ${ }^{1}$ The issues which I propose to discuss revolve around Government policies and actions designed for economic stabilization.

Until recently there was quite general acceptance of the view that there is basic instability in the economy which produces wide fluctuations in output and employment. Some recent studies have cast considerable doubt upon this view. In its place is proposed the view that there is a high degree of inherent stability in our economic system. According to this view, population, natural resources, capital formation, and technology determine growth in output of goods and services. Since these factors change slowly and exert a powerful influence, they provide great underlying stability to the trend growth of output and employment. However, it is also increasingly recognized that fiscal and monetary actions of the government can be a source of short-run instability since, if improperly used, such actions can force the economy off of a high-employment stable-price growth path. One of the most important controversies presently facing those of us concerned with stabilization policies is the choice of reliable indicators or summary measures of the ways fiscal and monetary actions of the government influence the economy. I would like to discuss this problem with you.

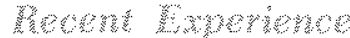

The recent record of national economic stabilization policy has left much to be desired. For almost five years we have had an accelerating inflation which we have not arrested either for lack of will or lack of knowledge as to how to do it. Uncertainty about the role of the Federal budget and about monetary policy has prevailed. Did the inflation come from the Federal spending, the budget deficit, monetary expansion or from some combination? Is the cure for the inflation to be found primarily in budget policy or in monetary policy?

The issies discussed in this speech have been presented to other groups recently by President Darryl R. Francis.
A recent experience with overt stabilization actions occurred last summer when taxes were raised and the growth rate of Federal spending was slowed. Some believed that these actions would bring the excessive growth of total spending under control quickly and would soon limit the rate of inflation. Yet, prices have continued to rise.

\section{Wern Whas}

More generally, we have heard a great deal in the Sixties about the tremendous success of various fiscal policies, and particularly deficit spending, in keeping the economy growing. Not too long ago, the financial press made frequent reference to the number of months since the last recession. The implication was that the economy - at long last - could be "fine tuned." However, as inflation has accelerated, we have heard fewer references to successes. Rather, attention has been focused on the need to dampen the excessive total spending.

With respect to fiscal actions, we are often reminded that the Federal Government cut taxes in early 1964, and that the economy has grown rapidly ever since. This observation generally implies a cause and effect relation, namely, that the growth we have experienced since the early Sixties has been chiefly a result of that 1964 tax cut.

Also, the total national debt has increased every year in this decade. It is widely believed that these deficits have kept the economy growing and, therefore, have been desirable. Then, last year, this great fiscal force was reversed in order to cool an overheating economy. Yet, so far the only thing that has cooled is the talk about the beneficial powers of fiscal action.

\section{Mondary}

In addition to fiscal policy, it is generally thought that monetary developments can influence economic activity. There are several monetary approaches. One focuses on interest rates and other money market conditions and another concentrates on credit. According to still another approach, the growth rate of the stock of money provides the best measure of the 
influence of stabilization actions on total spending. Money is defined as demand deposits plus currency. The Federal Reserve can manage the growth of money through controlling Federal Reserve credit and the monetary base. According to this view, the level or movement of interest rates or the growth of bank credit are frequently misleading.

I will approach the monetary view of economic stabilization by discussing the following points: First, why have budget measures recently failed? Second, more generally, how reliable have such measures been? Third, what are the merits of "money market conditions" compared with monetary aggregates as measures of monetary influence? Fourth, what may we conclude about desirable monetary actions in the near future and the probable course of the economy?

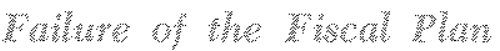

Both before and after Congress passed the budget package last summer we heard many different ways in which the impact of such actions would reach the economy. Let us talk about a few of these. One approach was to argue that since taxpayers would have $\$ 13$ billion less purchasing power as a result of the tax increase and the Federal Government would spend $\$ 6$ billion less than otherwise, a total of $\$ 19$ billion would be "taken out of the spending stream." It was further argued that, after the initial $\$ 19$ billion reduction in total demand, incomes would grow less than otherwise and increases in other spending would also be moderated. Because of this "multiplier" effect, the ultimate reduction in total spending would be several times the initial $\$ 19$ billion.

A second method of assessing the influence of the budget package was to note that the Federal cash deficit in fiscal 1968 was over $\$ 25$ billion, compared with only a $\$ 5$ billion deficit projected for fiscal 1969 . Hence, it was said that total spending in the economy would be at least $\$ 20$ billion less. If there were a multiplier effect, the ultimate reduction in total spending would have been much greater. Arguments along these lines ignore the way the deficit is financed, a point we will return to in a few minutes.

A third way of assessing the influence of the budget package on the economy was with reference to the change it would cause in a cyclically adjusted budget, commonly called the "high employment" budget. Throughout the early Sixties, this budget had been in large surplus, but the amount of this surplus began to shrink rapidly in 1964, and toward the latter part of 1965 moved into deficit. From about 1966 to mid1968 the deficit increased rather rapidly, reaching an annual rate of $\$ 15$ billion in the second quarter last year. Thus, this measure of the budget moved from a $\$ 15$ billion surplus at the end of 1963 to a $\$ 15$ billion deficit in mid-1968. Then, in mid-1968 it was planned by means of the surtax and the cut in the growth of Federal spending to swing the budget back from the $\$ 15$ billion deficit a year ago to a $\$ 10$ billion surplus in the present quarter. According to popular analysis, this swing in one year was to provide a "massive dose of fiscal restraint."

In our judgment, the spending-stream view, the deficit view, and the high-employment budget view of assessing the influence of the fiscal package of June 1968 on total spending in the economy overlooked several key points. One question is whether the surtax would really reduce total spending or merely redistribute it. When the Federal Government obtains funds by taxing rather than by borrowing from the public, taxpayers have less to spend, the private investors have more. Total demand for the goods and services in the economy is not necessarily changed. Similarly, if the Government decision to spend less means only that less taxes will be collected and/or the Government will borrow less from the public, then total spending-Government plus private - may not be affected.

A key point in evaluating the effects of such increased taxes is the question of what the Government would have done as an alternative, and what would have been the source of its command over resources if taxes had not been increased?

When the Federal Government operates at a deficit it means that the Government spends more than it takes in through taxation. But this does not mean that the Government really spends more than it takes in, since it borrows an amount equivalent to the deficit. Total demand is only increased if the deficit is financed by newly created money, as it has been for much of this decade and especially in 1967 and 1968. If, as the Federal Government runs a deficit and increases its sales of bonds, the Federal Reserve adds to the total reserves of the banking system by purchasing securities on the open market, then total purchasing power is increased. The source of this increase in total purchasing power and demands for goods and services flows from the newly created money, not from the deficit per se.

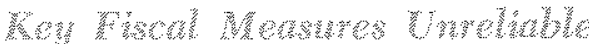

An analysis which uses the budget as a measure of the influence of stabilization policies on the eco- 
nomy is incomplete. I am not familiar with any theory, nor any empirical evidence, which supports the use of this measure alone. The high-employment budget moved sharply into deficit during 1966 and 1967, indicating a high and accelerating degree of fiscal stimulus. As a result, the economy was expected to remain very strong. According to any commonly used measure of fiscal influence, the pause in the growth of total spending in early 1967 was unexpected and, in retrospect, unexplainable. Similarly, the sharp swing in the high employment budget from large deficits to large surplus after mid-1968 supposedly indicated a massive dose of fiscal restraint. However, we have yet to see the results of this fiscal action. Furthermore, recent research at the Federal Reserve Bank of St. Louis has cast considerable doubt on the use of changes in the high-employment budget as a measure of either fiscal or overall stabilization influence on the economy.

In short, the way the deficit is financed makes a crucial difference in determining how much stimulus is indicated by a budget deficit or how restrictive an influence results from a surplus.

We have no reason to believe that large deficits such as we have had in the Sixties are in themselves any more stimulative to total spending than the relatively small deficits in the Fifties after the Korean War. What matters is how much monetary creation accompanies the deficit. Therefore, when actions were taken last year to substantially reduce the deficit, the relevant questions for assessing the restraining influence of such action should have been: What will be the change in the rate of money creation? And, how long will it take before any slowing in the rate of monetary creation begins to slow total spending? Since the rate of monetary growth has since slowed only gradually, it is not surprising that there has been no reduction in the rate of inflation in the first three quarters following the tax increase.

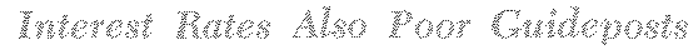

Since it appears increasingly clear that monetary actions are the prime stabilization influences in the economy, I would like now to consider the choice between the growth of a monetary aggregate such as the money supply and "money market conditions" or movements in interest rates as the primary indicator of monetary actions. One criterion for choosing an indicator of the influence of monetary actions from among the various available monetary variables is that movements in the indicator be attributable to policy actions. The policymakers must be able to know what they have done.

Financial and business publications make frequent reference to tight and easy money, and we all know what these words generally imply in terms of interest rates. High or rising levels of interest rates are often misjudged as tight money and low or falling rates are often thought to be a sign of easy money. But what is really meant, is that credit is tight or easy, and it throws no light on what influence on total spending is being exercised by the monetary authority.

The Brazilian economy has typically experienced a very rapid rate of inflation and, simultaneously, interest rates of about 40 per cent. These high interest rates were a result of a very easy or inflationary monetary policies rather than a sign of monetary restraint. On the other hand, if we examine the experience in the Swiss economy, we find that interest rates have typically been the lowest in the world, averaging around 2 or 3 per cent. Once again, I think that we could agree that these low interest rates in Switzerland have, in large part, been a result of public policies of restraint.

Why is it then that high or rising interest rates, coupled with accelerating inflation, really represent expansionary policies, and that if interest rates decline this would indicate monetary restraint? This is not a new paradox. It was recognized many years ago that actual market interest rates are equivalent to the expected rate of productivity of real capital plus the rate of anticipated price increase over the term of the loan. For instance, if the marginal productivity of capital is currently estimated to be about 3 per cent a year, and most lenders and borrowers expect inflation for the indefinite future at about 3 or 4 per cent per year, one would expect market rates of interest of 6 to 7 per cent. Is there one of us here today who would be willing to lend our money for the indefinite future at a 4 per cent rate if we expected the rate of price increases to be 4 per cent per year more or less indefinitely?

My point is that market rates of interest are directly responsive to supplies and demands of funds in the capital markets. Any changes in the demands for or in the supplies of credit by the private sector of the economy cause changes in market interest rates. In addition, any change in the flow of funds from Treasury operations, changes in international liquidity flows, expectations about future events, international crises, etc., call for fluctuations of interest rates. Acceptance of the effect of all of these factors on interest rates makes it only slightly less than amazing 
that we still frequently hear references to movements in interest rates or changes in "money market conditions" as a measure of the "tightness" or "ease" of monetary policies. Can stabilization policymakers in this country use interest rates as their indicators if they cannot assess the influence of their own actions on interest rates?

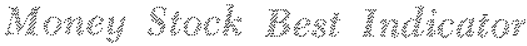

On the other hand, we have a theory which says that changes in the growth rate of the money supply cause changes in total spending in the same direction. To support this theory there is substantial empirical evidence indicating that marked and sustained changes in the rate of growth of the money supply have always been followed by changes in the growth of total spending in the same direction. Research indicates that changes in the growth of money have been fully manifested on total spending within a few quarters.

The Federal Reserve System, through its power to create and destroy bank reserves, can control the money supply. Since there are close causal links between changes in Federal Reserve actions and in the money supply and between changes in the money supply and changes in spending, I submit that the money supply gives us the best overall measure of the influence of monetary policy actions.

An example of the difference between the use of interest rates and the growth of money as indicators of the thrust of monetary actions is found in early 1968. Throughout the first half of 1968 the Federal Open Market Committee agreed that a restrictive monetary policy was appropriate. However, at several of the Committee meetings, the proceedings of which have been published, some participants argued that a substantial degree of monetary restraint had already been achieved, as indicated by the high and rising market interest rates. Now it is true that interest rates rose rapidly through the first five months of last year, but these rising prices of funds were the result of very strong demands for credit enlarged by the anticipation that inflation would be with us for quite a while longer. If the rising interest rates a year ago indicated "a substantial degree of monetary restraint," then when will this economy feel the effects of that restraint?

In contrast to the unreliable signposts provided by interest rates, the money stock indicator pointed in the direction that the economy actually moved. The money stock grew at a very rapid 7 per cent annual rate in the first half of last year, about as rapid as in any six-month period in the past twenty years. This rapid monetary growth in early 1968 has since been stimulating the economy. It was not surprising to those who observe the economy from the monetary point of view that there was little slowing in total spending in late 1968 and early 1969, and no improvement in the inflation problem.

Most recently a monetary interpretation of the developments since this past December indicates that a substantial degree of monetary restraint has been achieved, but the ultimate impact of this restraint on total spending will depend on its duration.

The money stock increased at less than a 2 per cent annual rate from last December to March, which our research shows was a sufficient degree of monetary restraint to eventually bring an end to the inflation. However, in April some special factors caused money to jump sharply, and the level of money remained fairly high in May. Indications now are that the growth of money from the first to second quarter will be about the same as the fourth quarter last year to the first quarter; I think we have made substantial, although not yet sufficient, progress towards attaining the necessary monetary restraint.

The available data, combined with statements of policymakers, indicate that sufficient monetary restraint probably will be achieved, and if so, in the second half of this year smaller increases in total spending can be expected. Slowing in the growth of total spending will be accompanied at first by a slowing in the growth of real output, a decline in business profits, and a temporary rise in unemployment. On the more favorable side, such conditions would start reducing inflation, and as inflationary expectations recede, market interest rates will probably decline.

Let me summarize in a few words the message I hope gets through from all I have said this morning. It is my confident belief that the long-run best interest of all the people in this country is best served by a Federal budget that is in balance or even moderate surplus. Within the framework of a balanced budget, monetary policy can create and maintain an economic atmosphere that is conducive to optimum economic growth, effective full employment, and a constantly improving standard of living for all. The record of the recent past has been sufficiently overt to convince thoughtful people that further fine-tuning budget experimentation can lead only to the injection of unnecessary instability into an otherwise inherently stable economic system. 